\title{
The Dagbamba Damba Repertoire
}

\author{
Rashid, Mohammed Abubakari \\ E. P. College of Education \\ P. O. Box 16 \\ Bimbilla
}

\begin{abstract}
The paper focuses on the Dagbamba, a Mabia language spoken in Ghana's Northern Region. The paper discusses 'opening', 'invitation', 'welcoming' and 'goodbye' songs of the Damba repertoire (Damba yila). Shownin the paper, is the 'opening song', 'invitation song', 'welcoming song' and 'goodbying song' specifically performed to begin,invite, welcome the king to the grounds and goodbye the king or thank the king respectivelyin the Damba repertoire. The paper illustrates that the structure and form of the repertoire are in short verses. It also illuminates the underlying major themes such as reverence, caution, fidelity and gratitude. Further, the papershows some literary devices employed such as repetition, assonance, alliteration and many others. The paper concludes in recognition of the difficulty of determining the exact stanzas of the Damba repertoire as the performer's unconsciousness of the formal grouping. Evidently, the paper concludes that the Damba repertoire goes beyond mere performance.
\end{abstract}

Keywords: Dagbamba, Damba, repertoireand performance

\section{Introduction}

This paper discussesa literary study of Damba repertoire(Damba yila) among the Dagbamba, the speakers of Dagbani, spoken in Northern Ghana.The language is classified among the MabiaLanguages, a component ofthe Niger-Congo language family (Bodomo, 1996: 36).

Yila 'songs' have attracted the attention of many literature scholarsbut the opposite is true in the case of the Dagbamba Damba repertoire.One can only find works on the various festivals as in the likes of (Mahama 2004, Tia 1969:14, Literacy and Development Through Partnership 2007:17-18).

Festivals such as Kpini ficbbu'guinea fowl whipping', Buyum 'fire festival', and many more are discussed. There is also a mere mentioning of the Damba repertoire as part of the activities performed during the Damba celebration.But these works lack analysis which triggered this study.

In this paper, I try to discuss the structure of the Dagbamba Damba repertoire with respect to the opening, invitation, welcoming and goodbye.Interestingly, it is not every song of the repertoire that opens a performance, invites or welcomes the king to the performance ground and or goodbyes the king from the performance grounds after responding to the performers call to the grounds to bring sanity in the performance. These and many more treasures are hidden in the Dagbamba Damba repertoire that needs to be laid bare in the literature for public consumption. The literary techniques employed by the performers are also discussed in this paper.

Primary data is taken from the Eastern dialect (Nanuni) is used in this descriptive analysis.

Reverence, caution, obedience and fidelity are themes associated with specific songs but praise evidently could be the major theme in the entire Damba repertoire becausetheypurposely praise the king and the legacies ofhis ancestors.

\subsection{Overview}

Tia (1969) opines that Damba was first brought by the 'Mallams' of the 'Mandigo' people to Dagbay which eventually became well known celebrated festival during the regime of Naa Zanjina. Damba in 'Mandigo' means a big dance. Probably, the brain behind the festival beenseen as the most important festival among the Dagbamba is for it been introduced to the Dagbamba by 'Mallams' who are believed to have some sound spiritual backings. Traditionally, the Damba dance is also seen as the most recognized dance and mostly called the royal dance among the Dagbamba. Damba festival is the second festival after fire festival that also bears the name of the month celebrated in the third month on the Dagbamba lunar calendar within a year. Culturally, the Damba festival is accorded the most important festival among all the festivals among the Dagbamba. This is manifested in the lives of the Dagbamba as soon as the month is sited. Guardians, parents and husbands usually receive pressures from children and wives to buy them new attires to be used during the celebration and also to prepare for relatives who will be coming down from cities to celebrate with them. 
Husbands who also have their wives staying in their respective homes due to child birth will be asked to come back to their marital homes as soon as possible to enable their husbands receive the visitors since it is not proper to receive a visitor without someone to keep the house during this celebration. The celebration hasbiyymaa 'smock' and zupiligu 'a hat' among the males and bimmayli 'a locally made cloth also used for sowing smocks' with any top and bimmayli bsbiga 'a veil made up of the cloth used in sowing a smock' for females both young and old as a unique dress code. This makes the festival a unique one among the Dagbamba and every Dagbana will want to be part of the celebration at all cost. Though, not the same importance have been placed on the festival as it was some years back, most Dagbamba still attach significance to the celebration.

\section{The origin of Damba}

There are divergent views in terms of the origin of the Damba festival among the Dagbamba. One school of thought is of the view that, it was during the regime of Naa Zanjina, one of the early kings of Dagbay,Islamic religion first emerged in Dagbay. The Mallams at that time use to celebrate the birth of the Holy Prophet Muhammad (PBUH) in the month of Damba. This celebration actually starts as soon as the month of the birth of the Prophet (Damba) is sighted till the day that is said to have been the naming day of the Prophet. According to this school of thought, Dan 'tooni/Somo(a chieftaincy title of one of the elders in the palace) Damba'first Damba' falls on the day the Prophet was born that is the eleventh day of the Damba month. Normally, on the tenth day, also the eve day to the SomoDamba. Laabannaa (a chieftaincy title of the people knownamong theDagbamba asLaabansi) and Somo goe to the king's palace forshigkaafa gahimbu 'rice picking' in the evening, when the sun is about to set. During this activity, certain Quranic verses that literally means, 'Allah Himself has bestowed peace and blessings upon Muhammad the messenger of Allah. Oh my God, let peace and blessings prevail upon Muhammad the messenger of Allah. Everlasting peace and blessings belong to only Allah. Allah and His angels have all blessed Muhammad the messenger of Allah.'These recitations are accompanied with drumming after every completion of the verses. The essence of this'rice picking' is to remove unwanted materials in the rice. After picking out the unwanted materials from the rice, the rice will be fetched withymangbaa 'a spoon made from guard' for the chief and his elders to chew, just to be sure that there are no more foreign materials in the rice. The rice is also fetched for Laabannaa and Somowith the same spoon for the same purpose.Then, the rest of the elders at the scene will fetch to also chew. The remaining rice will be added to grinded maize to prepare rice balls on the following day evening, also the day ofSomoDamba. This is distributed to the elders/sub-chiefs who have come from within the paramountcy to celebrate with them as they welcome the newly born Prophet to this earth. The cow which is to be slaughtered after circumbulating around it with the recitation of the same Quranic verses recited during the picking of the rice also accompanied with drumming after every completion of each round of the recitation and circumbulating three times. This activity usually takes place at the early hours of the day, mostly done around 10:00am. After circumbulating round the cow three times, the cow is slaughtered.During this time of slaughtering, the umbrella of the king is lowered to cover the face of the king to prevent him from seeing the cow being slaughtered and the blood oozing out. Somo who holds a swordwith a cola on the tip used as a walking stick, deeps the cola into the blood oozing out of the slaughtered cow and shows it to the king in the lowered umbrella.The king then uses his finger to touch the blood on the cola andrub it on his forehead.This is believed to have some spiritual backings in relation to the kinship and also confirms to the king the slaughtering of the cow. The meat of the cow is used to prepare soup for the rice balls and shared to the elders/sub-chiefs. After this circumbulating of the cow, the morning Damba starts immediately after the killing of the cow. These same activities are repeated in theNaa Damba'second Damba' which also falls on the seventh day after the Somo Damba and the day the Prophet was named. It is believed that, bothSomo andNaa Damba falls on the day the Prophet Muhammad (PBUH) was born and named respectively.Thus, the dancing is to rejoice on the birth of the Holy Prophet.Hence, Damba festival is celebrated to commemorate the birth and naming of Prophet Muhammad (PBUH), the view held by this school of thoughts (Tia 1969: 14; Literacy and Development Through Partnership 2007:17-18; Rashid 2017: 203).

On the contrary, some school of thought affirms that, Damba festival existed before the introduction of Islam in Dagbay. However, Dagbamba already had a month in their calendar that bears the name of this festival. Again, the dance named Damba for the royalty existed before the coming of Islam. The question this school of thought asks is whether Dagbay existed before the introduction of Islam or not.If yes, then the festival belongs to Dagbamba and existed long before the introduction of Islam in Dagbay. Dagbamba already had Damba as a name of a month in their calendar and also as a name of a royal dance and since the Dagbamba calendar existed before the introduction of Islam in Dagbay, Damba was not introduced first by Mallams who believed to have brought Islam to the kingdom(Mahama, 2004). In my own humble opinion, Damba originated from the Dagbamba through Islamic religion and was also first brought to Dagban by 'Mallams' who are seen to be leaders of the Islamic religion. 
It is not by coincident that the days of celebration fall on the exact birth and naming days of the Prophet Muhammad (PBUH) thoughDamba happens to be a month's name in the Dagbamba calendar. This might have been named after the 'big dance' in 'Mandigo' and subsequently extendedits name to the month and the festival as well. Rashid (2017: 203) conforms with this assertion as he says "Traditionally among the Dagbamba, events are used to measure or calculate time or sequence of events in the past." That is, the naming of the Dagbamba calendar months follow events within this period.Therefore, all the months bearing the same names with an event among the Dagbamba got their names from the events that takes place within that month. Furthermore, McGaffey (2013) asserts that they may have been no drummers until Naa Zanjina's regime when the drummers were imported from Hausaland. These Hausas are believed to be Islamically inclined and could have introduced some of their cultures to the Dagbamba. Again, all the festivals celebrated among the Dagbamba exceptBuyum 'Fire festival' have some Islamic lineage. For instance, Kpini ficbbu 'guinea fowls whipping' came to existence as a result of the refusal of the guinea fowl to offer the Prophet water when he and his followers were thirsty.As for the Konyurichuуu 'Thirst/water drinking festival' and Chimsi 'ram sacrificial festival', are all festivals celebrated by Muslims worldwide. These festivals are also celebrated among the Dagbamba and all these festivals bare the same names with theirmonths and celebrated among the Dagbamba. Also, the recitations of the Quranic verses during the rice picking and the circumbulating the cow is done to give thanks to the Almighty Allah for the birth of the Prophet would not have been part of the celebrations if the festival was not introduced by the mallams. This is possibly due to the dynamism in culture as Ababio (2005) observes. He says "Culture accommodate and collaborate with religion but it can also estrange or capture religion." Ababio (2005) further states that "Religion can reform or transform culture." The culture of the Dagbamba might have undergone some religious transformations as it accommodated and collaborated with the Islamic religion during its introduction.All the activities performed during the Damba, right from the sighting of the moon to the last day of the festival celebration are aimed at rejoicing over the birth and preparation towards the naming of the Holy Prophet Muhammad (PBUH) though this festival is not celebrated by Muslims worldwide. Therefore, Damba is performed to commemorate the birth and naming of the Holy Prophet Muhammad (PBUH).

\section{Damba repertoire (Damba yila)}

As part of the celebration and the most central part of this paper, songs are performed during this celebration. The performance of the Damba repertoire is part of the salima 'praise-singing'. Salima'praise-singing', according to MacGaffey (2013: 36) is a form of epic poetry and a primary art formthat includes complex repertoire of rhythms that accompanies the ceremonies of chieftaincy, closely associated with the Dagbamba identity. From the day theDamba moon is sighted to the last celebration, women are normally gathered in the palaces of important chiefs to perform at night the Dambarepertoire to entertain and praise the chiefs as they relax in their chambers. These Dambayila 'Damba songs' are transmitted orally with unknown composers and are learned informally and performed orally in a simple style. The Dagbamba repertoiremay be accompanied with instruments or not during the performance. Songsas one of the forms of communications, creates opportunity for the identification of some prominent people and the legacy they left behind, why and how things were done or not done among some groups in the society (Sanortey, 2012). The DagbambaDamba repertoire are thus performed not just for the purpose of entertaining the king but it also givessome emotional bonding between the king and his ancestors. They are also performed to praise the king and remind him of whom he is and also performed to promote social cohesion. Indeed, for them being normally termed as Damba yila 'songs' are because they are obviously not performed at any time apart from being colourfully performed to commemorate this long term celebrated Damba festival. They aremostly performed during the night after supper at a time when everyone has finished with the house chores and are gathered at the king's palace, and continues, for a minimum of two hours till the performers are tired.

\subsection{Structure of the Dagbamba Damba repertoire}

The Dagbani Dambarepertoire are usually in short verses characterized by repeated choruses after the lead vocalist (LV). The songs are normally not performed in plain language but employ some literary terms to bring to bear their themes. There are specific repertoire the performers normally use to open the performance, invite, welcomethe kingto the performance ground or goodbye the king from the performance grounds, but no specific song has been identified for the closure.Thus anysong can be performed to bring to the closure of the performance apart from thesongs identified for the opening, invitation, welcoming and goodbying the king.There are other songsperformed but this paper concentrates on only the songs performed to open, invite, welcome and goodbye the king in the Dagbamba Damba repertoire. Theyare normally in a form of short verses which are performed in two forms; the first form consists of the lead vocalist introducing the song followed by the chorus and the rest of the song will normally comprise the repetition of the first verse performed together with praises of the king by the lead vocalist which is also followed by the repetition of the same chorus hence the Dagbamba Damba repertoire are in short verses form. 
Praises such as Dmantambo zuu 'the first son of Dmantambo (the founder of the Nanuy kingdom)', Shero yaantitaa 'the first grandson of Shero', Tibayba shira 'Tibayba's love/grandchild', Tintariga zuu 'outskirt's' first son', Gbuyum' baligu zии 'young lions' first son' (this means that the king being praised is from the Gbuуита 'lion' gate of the two gates in Nanuy kingdom succeeding so many sons of lions since they are all from the same ancestor). $N$ dintoli shira 'my own love/grandparent', Gbewaа zии 'the first son of Gbewaa', Bayilisaani zuи 'Bayilisaani's first son' (this is the praise of the royals of Dagbay who are descendants of Naa Gbewaa).Bayilisaaniwas one of the names of Naa Gbewaa.

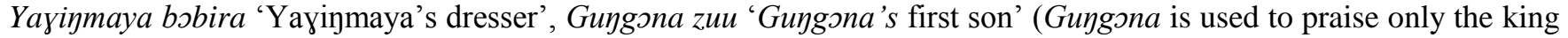
of Mampurigu, Dagbay and Nanuy.That is, the king or regents of the three kingdoms who happen to be descendants ofNaa Gbewaa). Gbuуита zии 'the first son of lions', Kurugu namda piri ku m-balim goo 'wearing metal sandals requires no begging of a thorn', Andani libazuи 'the first son of Andani who succeeded Andani who also succeeded Andani all climbing to the throne, liba'.Many more of similar praises are default praises in most of the Dagbamba Damba repertoire.Therefore, the praises used are not restricted to a particularsong, which enables the lead vocalist to select any praise she desires to use in any of the Damba repertoire. Notably, one word zuu 'first son' runs through most of the praises. This suggests that the king in the picture is either a regent or a substantive king of the kingdom who happens to be the first son of his father and has also succeeded in climbing the throne. The other words used in the repertoire are proverbial names such as Tibayba 'we have identified them', this was the name of the mother of the late Naa Dasana (a famous king) in Nanuy.The other proverbial names such as Kurugu kpaa 'iron stick', kpara nya wabigu

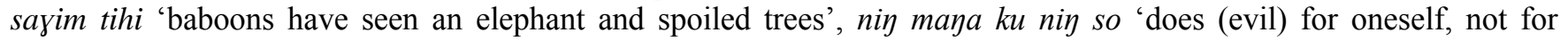
others', kuzicm bia 'won't despise a child' and gampil' suma layindi ban ziina'good ficus trees assembles those who reside' are the names of the successor on the throne's ancestors, except Yayiymaya which is also a name of the first place of settlement in Bimbilla. Interestingly, the names or praise names chosen by a great grandfather or fatherby extension could be used to praise the king on the skins.

As Saanchi (1992)observes, determining exactly what constitute a stanza in adirge among the Dagara will be difficult for the performer may not be conscious of the formal grouping of lines as a written poet would have done. Similar to Saanchi (Ibid) assertion, the exact determination of a stanza of the Dagbamba repertoire will be difficult as the performer is not conscious of the formal groupings. It is also the discretion of thelead vocalistto decidewhether to switch to a different songor to continue with the song being performed.This makes the lead vocalist prolongssongs shethinks have some messages of specific interest or boost the morale of the performers. The performers normally employ the technique of repetition in their quest to prolong the songs. This is seen in the song performed to open the Dagbamba Damba repertoire below.

\subsection{The opening/introductory repertoire}

Aninwula 'good evening' is the song that introduces the performanceof all the Dagbamba Damba repertoire. It is also the only song that can be performed to open the Dagbamba Damba repertoire. It is also performed to draw the attention of the king to the performanceand also signalthe king that it is no more day time but the night has come.The performers are greeting the king in other to be permitted to carry on their normal duties as hishouse wives andconsolers. Excerpt 1 below is the opening/introductorysong.

\section{Excerpt 1}

\section{Aninwula 'Good evening'}

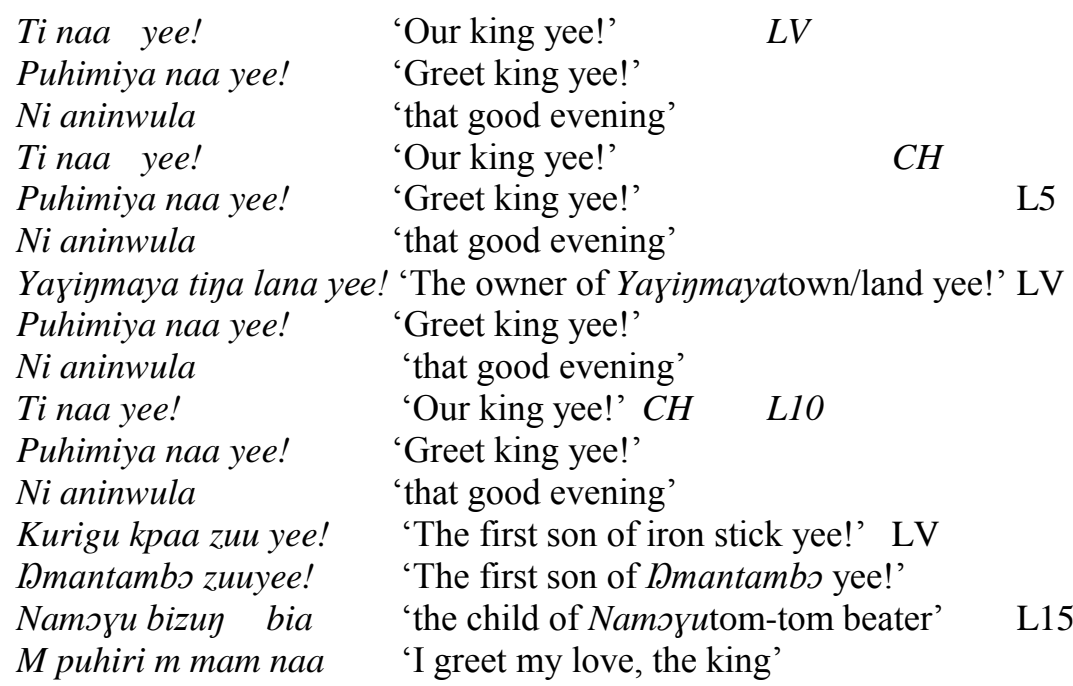




\begin{tabular}{|c|c|c|}
\hline Ni aninwula & 'that good evening' & \\
\hline Ti naa yee! & 'Our king!' & $\mathrm{CH}$ \\
\hline Puhimiya naa yee! & 'Greet king!' & \\
\hline Ni aninwula & 'that good evening' & L20 \\
\hline $\begin{array}{l}\text { Ja' liba yaantitaa yee! } \\
\text { Ti nindi naa yee! 'We are }\end{array}$ & $\begin{array}{l}\text { 'The first grandchil } \\
\text { e saying to the king!' }\end{array}$ & several twins!' \\
\hline Ni aninwula & 'that good evening' & \\
\hline Ti naayee! & 'Our king!' & $\mathrm{CH}$ \\
\hline $\begin{array}{l}\text { Puhimiya naa yee! } \\
\text { Ni aninwula }\end{array}$ & $\begin{array}{l}\text { 'Greet king!' } \\
\text { 'that good evening' }\end{array}$ & $\mathrm{L} 25$ \\
\hline
\end{tabular}

The above song which is in a form of short verses is performed only at the beginning of the performance session of the Dagbamba Damba repertoire to register the presence of the performers in the palace to the king.That the king's wives are gathered, needing permission from the king to perform.As part of the Dagbamba culture, nobody goes into any house to do something without seeing the landlord of the house for the necessary permission. In an event there is a problem as a result ofwhatever one is doing under the landlord's jurisdiction. The landlord will know how to deal with the problem and solve it accordingly. To some extent, the Dagbamba has it that if no permission is taken from the landlord and going on to do anything without the knowledge of the landlord,amounts to gross disrespect.Therefore,the opening song Aninwulais performed to seek permission from the king for the commencement of the performance of the repertoire. It has caution and reverence as its themes. The opening verses Puhimiya naa yee ni aninwula 'greet the king yee that good evening' of this songis greetings to the king symbolizes the request of the permission from the king.It also creates the king's awareness that whatever follows afterwards should not be a surprise to the king. This song has five and three words as the longest and the shortest words respectively in a verse. The lead vocalist introduces praises of her choice into the verses but some of these verses are the short versions of some proverbial names picked by some of the king and his grandparents. For instance,Kurigu kpaa zuu as seen in this song is the short version ofChichayili ksbiga che kurigu kpaa yela, wurikoo di mali karimbaani 'a hundred termites stopped trying to eat up an iron stick/peg; the white ants should not be bragging'.This means that, weak persons should not boast about doing what greate persons have failed to do. But whether said in full or not the intended meaning and referent is known. The number of praises within the Dagbamba Damba repertoire in a stanza is not readily determined.Notably, the highest number of praises used by the lead vocalist is five. The introductions of more than five praises by the lead vocalist will gradually turn the song into a speech.

\subsection{The invitation repertoire}

Another song in the Dagbamba Damba repertoire is Mali waa 'fix up the dance'. ThissongMali waa 'fix up the dance' invites the king to the performance ground when the performers seem not to have concentration in the performance or carried away by some otherthings during the performance. It is performed to invite the king to come out and put sanity into the performance as he is seen to be the number one respectable and most obeyed being amongst all the community members. The song when performed actually arouses the interest of the king and often drags the king immediately out to be with the performers for some time just to actually bring back the minds of the performers before taking leave of them when everything is in the right move. The king as matter of tradition will offer the performers something to cool their throat as they may be thirsty as a result of the continuous singing. The invitation song is seen in excerpt 2 below.

\section{Excerpt 2}

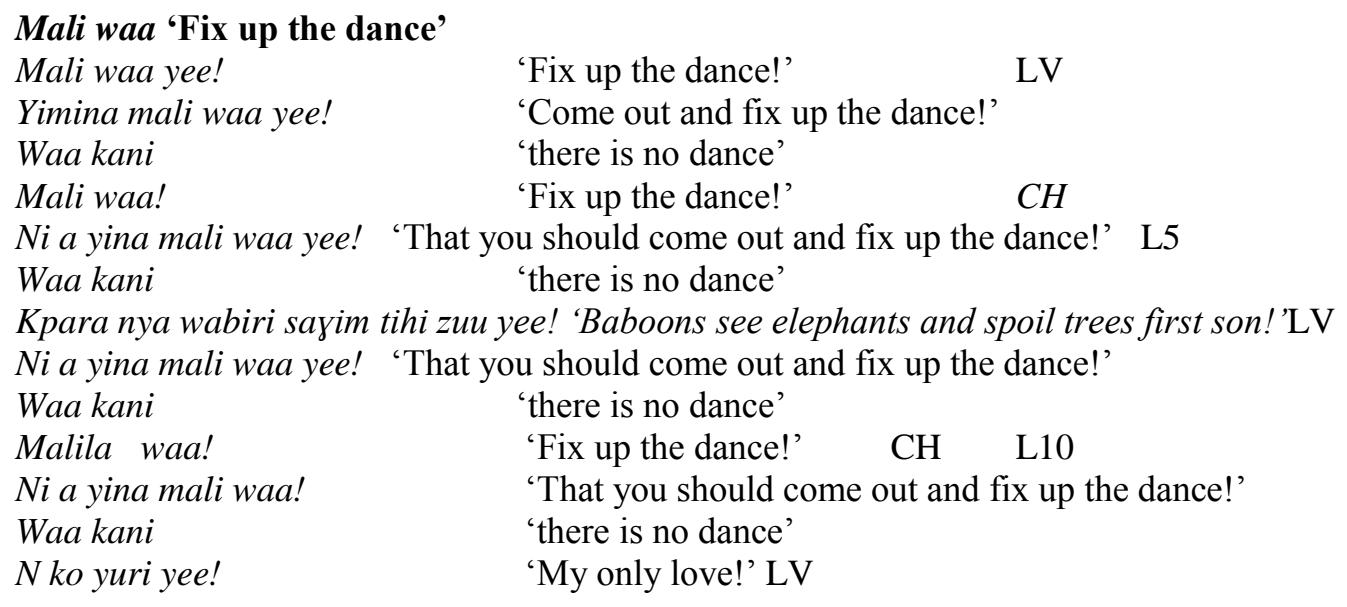




\begin{tabular}{|c|c|c|}
\hline Yimina mali waa yee! & 'Come out and fix up $t$ & he dance' \\
\hline Waa kani & 'there is no dance' & L15 \\
\hline Mali waa! & 'Fix up the dance!' & $\mathrm{CH}$ \\
\hline Ni a yina mali waa! & \multirow{2}{*}{\multicolumn{2}{|c|}{$\begin{array}{l}\text { 'That you should come out and fix up the dance!' } \\
\text { 'There is no dance!' }\end{array}$}} \\
\hline Waa kani! & & \\
\hline Niy maya ku niy so zuu & \multicolumn{2}{|c|}{ son of does (evil) for oneself, not for others' LV } \\
\hline $\begin{array}{l}\text { Ni a yina mali waa yee! } \\
\text { Waa kani }\end{array}$ & \multicolumn{2}{|c|}{$\begin{array}{l}\text { 'That you should come out and fix up the dance!' L20 } \\
\text { 'there is no dance' }\end{array}$} \\
\hline Mali waa & 'fix up the dance' & $\mathrm{CH}$ \\
\hline Ni a yina mali waa! & \multirow{2}{*}{\multicolumn{2}{|c|}{$\begin{array}{l}\text { 'That you should come out and fix up the dance!' } \\
\text { 'There is no dance' }\end{array}$}} \\
\hline Waa kani! & & \\
\hline Kи зівт bia yee! & 'Won’t despise a child!' LV & L25 \\
\hline $\begin{array}{l}\text { Ni a yina mali waa yee! } \\
\text { Waa kani }\end{array}$ & \multicolumn{2}{|c|}{ 'That you should come out and fix up the dance' } \\
\hline Mali waa & 'fix up the dance' & $\mathrm{CH}$ \\
\hline Ni a yina mali waa & \multicolumn{2}{|c|}{ 'that you should come out and fix up the dance' } \\
\hline Waa kani & 'there is no dance' & L30 \\
\hline
\end{tabular}

Theperformance of the invitation song Mali waa 'fix up the dance' is normally done to invite the king to the performance grounds.Literally, mali means to own/create/settle. Sometimes the king is referred to as the owner/creator/settler of something. Therefore, it is the owner/creator/settler who can actually put things in order when they are going wrong. Whenever the lead vocalist thinks the performers are carried away by certain things that affect the performance. It calls on the king to come out and fix up the situation and whenever it is performed, it givesall the performers a signal that the king may come out pretty soon. This brings back comportment in the performance because none of the performers would like the king to come out and meet her doing something else which may displease the king.Therefore to show respect to the king every performer would bring back her attention to the performance. Though it is not always the case that the king comes out upon listening to this invitation song performance.But nonetheless the invitation songis performed purposely to invitethe king but the king could be out or not depending on his discretion. And whether the king comes out or not, the purpose of the performance of this song is achieved since the performers comport themselves whenever it is performed due to the respect every individual accord the king. Therefore, the invitation song Mali waa 'fix up the dance' therefore has the themes of obedience and reverence. The performers thus put in their best to win the attention of the king. The song can be performed only at a time when the performers lost concentration in the performance. It bears the same form with the others that is, the invitation song is in a form ofshort lines.A call is made to the king in a form of a command, that is Yimina mali waa yee! 'Come out and fix up the dance!' in the second lineof the song. The lead vocalist commands the king to as a matter of urgency come out. This can be deduced from the use of the wordyimina! 'Come out!' though the lead vocalist could not have commanded the king on a normal day. A reported speechNi a yina mali waa yee! 'That you should come out and fix up the dance yee!' is used in the performance by the chorus performers to re-echo the call of the lead vocalist. In other words, the chorus performers are trying to suggest that it is the lead vocalist who has seen some ill performance on the part of the other performers, otherwise they have not. Hence the call by the lead vocalist for sanity to prevail in the performance. Nin maya ku niy so zuu 'the first son of does (evil) for oneself, not for others' in line 19 is a praise and a proverbial name too is giving praises to the father of the king who was concerned only of the welfare of his subjects even if he would not benefit. Again, Ku zicm bia yee! 'Won't despise a child yee!' signifies that, the king does not discriminate among his subjects even if the person is a child though, the Dagbamba believe that a child is always the looser if the bone of contention is between a child and an elder. But, the king will pronounce the child the winner over the elderly if the child wins a case. The king therefore respects everybody, whether young or old.The rest of the verses are repetition for emphasis. For example, mali waa'fix up the dance' andwaa kani'there is no dance' are repeated to emphasize on the need to fix up the performance. The idea of waa 'dance' replaces the singing performance since they are related. It is also established among the Dagbamba that whoever performs praises to the king is a wife of the king, therefore the performers introduce $N$ ko yuri yee! 'My only love yee' to show the relationship that exist between the king and the performers.

\subsection{The welcoming song}

This song of the Dagbamba repertoire is introduced during the performance to welcome the king to the performance ground. After a call is made by the lead vocalist to the king to come out and put things in order, when she realizes that the performers are carried away by different activities. It is called Binsaa 'Diarrhoea' and normally performed to the king to show allegiance to the skins on which he is seating on. Below is the song in excerpt 3. 


\section{Excerpt 3}

\section{Binsaa 'Diarrhoea'}

Binsaa! Binsaa! Binsaa!

Miri m bia yee!

Wabigu yen no ma yee!

Bini zuu di no ma!

Binsaa! Binsaa! Binsaa!

Miri m bia!

Wabigu yen no ma

Di no ma!

Gbuyima zии yee!

Wabigu yen no ma yee!

Gbuyim' baligu zuи yee!

Wabigu yen no ma

Dmantambo bobiri yee!

Wabigu yen no ma

Napaya bimbicmlana zuи yee!

Wabigu yen no ma

Di no ma!

Binsaa! Binsaa! Binsaa!

Miri m bia

Wabigu yen no ma

Di no ma!

Binsaa! Binsaa! Binsaa!

Miri m bia!

Wabigu yen no ma yee!

Binsaa! Binsaa! Binsaa!

Miri m bia

Wabigu yen no ma

Di no ma!

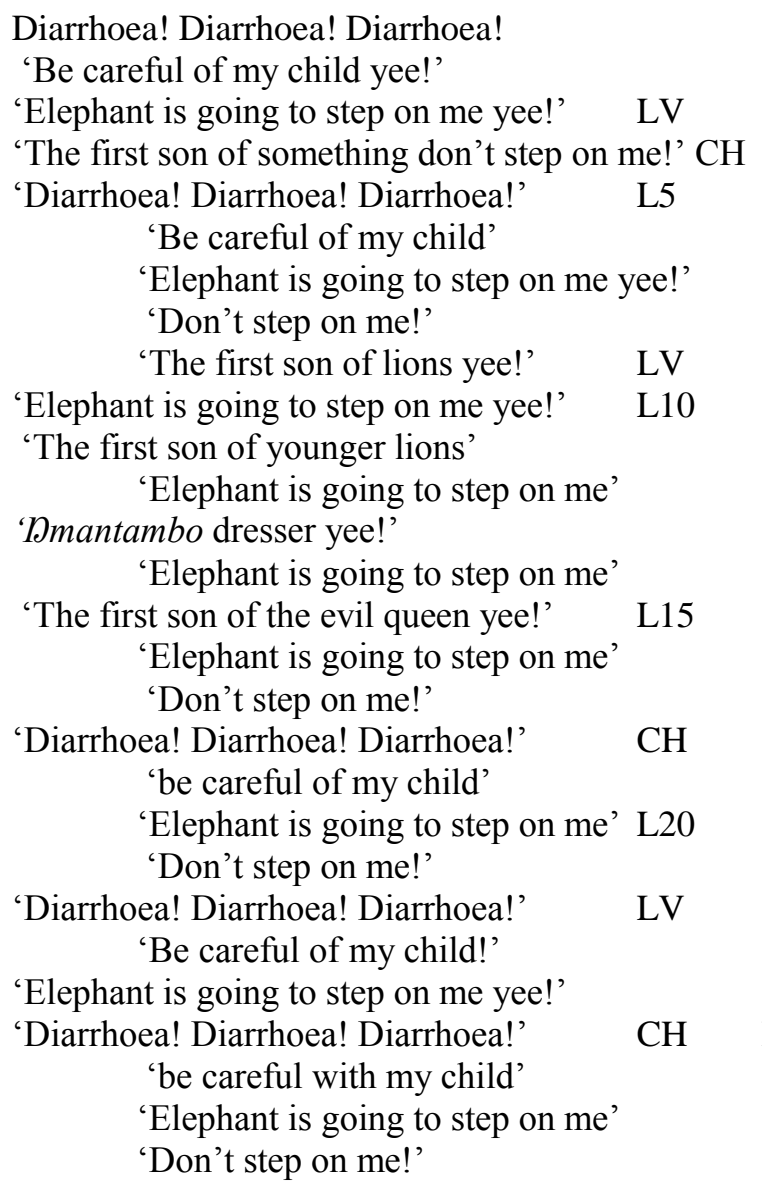

The performers perform excerpt 3 to welcome the king to the performance grounds. It has a similar structure and form as the opening song. It is also performed in a metaphoric language used to liken the king to the biggest animal,elephant.And they being the grass under the animal and can therefore be stepped on by the elephant as it steps on the grasses and smaller animals. It is believed that the king has super powers as he is closer to the ancestors than any one is and liable to doing anything to them under his powers trying to plead with the king not to actually do something to them, that they mean no harm, simply putting the king at a very higher position and seeing themselves at the lowest. Sometimes, for the fear of been victimised by the king since he is responding to anearlier call made to him to come out and bring back the attention of the performers. They perform this song to plead with the king to temper justice with mercy since the performers can be punished for not giving the performance the needed attention. The performers are cautioningbinsaa 'diarrhoea' to stay away from the child because it is seen as a killer disease in children. This can be seen in the verseMiri $m$ bia 'be careful with my child'.It has seven words in a verse as the longest words used and two as the shortest word in a verse. It is performed to pay some allegiance to the skins on which the king is seating and also cautioning the king not to harm them hence it has a major theme of fidelity and caution. The verse Wabiguycn no $m a$ 'elephant is going to step on me' likens the king to an elephant.Napayabimbicmlana'the evil queen' is one of the praises been used by the performers in this song. This exposes the world of the queens in the quest to make their sons ascend the throne. It is believed among the Dagbamba that, only the sons of powerful queens succeed the father. The Dagbamba have the belief that, it takes only a powerful royalist to ascend the throne of the king and having a mother who is spiritually powerful gives the person an added advantage over others. There is all forms of evil doing in the quest to become a successor of the throne. As it is, one can only ascend the throne when the one on the throne dies in the case of the king or move a step forward or die in the case of the sub-chiefs. So the successor will go extra mile just to also ascend the throne even if he has to eliminate the king or chief. This thus need some spiritual backings, the queen therefore will help the son to ascend the throne in any form. This necessitated the introduction of the praise Napaya bimbicmlana zuи'the evil queen's first son' which means that the mother of the king is evil that is why he has succeeded in ascending the throne. 


\subsection{The goodbye song}

Mudaasi 'thank you' song of the Dagbamba Damba repertoire is normally performed to say a farewell to the king and to also thank the king for taking some time out of his busy schedules leaving all what he is doing and come out to be with them for some time. Normally, before the king takes a leave of them, he also gives out some amount of money for water as the performers throats might be dried during the performance. In returns, the performers perform Mudaasito also show some appreciation to the king for being concern of their welfare. Below is the goodbye song in excerpt 4.

\section{Excerpt 4}

Mudaasi 'Thank you'

Mudaasi! Mudaasi! Yee!

Mbo yee!

Mudaasi! Mudaasi! Yee!

Mbo yee!

Guygona zuи yee!

M puhiri a mudaasi yee!

Mbo yee!

Mudaasi! Mudaasi! Yee!

Mbo yee!

Gampil' suma layindi ban ziina yee!

Mudaasi! Mudaasi! Yee!

Mbo yee!

Tibayba shira yee!

M puhiri a mudaasi yee!

Tintariga zuu yee!

M puhiri a mudaasi yee!

Bayilisaani zuи yee!

A mam puhiri a mudaasi yee!

Zuyukpuna bsbira yee!

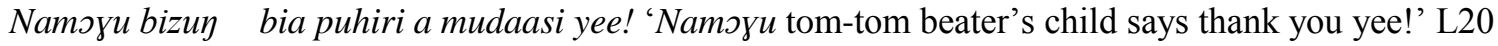

Mudaasi! Mudaasi! Yee!

Mbo yee!

Mudaasi! Mudaasi! Yee!

Mbo yee!

Mudaasi! Mudaasi! Yee!

Mbo yee!

\author{
'Thank you! Thank you! Yee!' LV \\ 'Well done yee!' \\ 'Thank you! Thank you! Yee!' CH \\ 'Well done yee!' \\ 'The first son of Guygona yee' L5 LV \\ 'I say thank you yee' \\ 'Well done yee!' \\ 'Thank you! Thank you! Yee!' CH \\ 'Well done yee!' \\ 'Good ficus trees assembles those who resides yee! L10 LV \\ 'Thank you! Thank you! Yee!' CH \\ 'Well done yee!' \\ 'Tibayba's love/grandchild yee!' LV \\ 'I say thank you yee!' \\ 'The first son of outskirts yee!' L15 \\ 'I say thank you yee!' \\ 'Bayilisaani's first son yee!' \\ 'Your love says thank you yee! \\ 'The clean-shaven heads dresser yee!' \\ 'Thank you! Thank you! Yee!' CH \\ 'Well done yee!' \\ 'Thank you! Thank you! Yee!' LV \\ 'Well done yee!' \\ 'Thank you! Thank you! Yee!' L25 CH \\ 'Well done yee!'
}

The above excerpt is only performed to the king when the king thinks he has brought back sanity into the performance and returning to his chamber to allow the performers continueafter he has shown the performers some appreciation by giving them something which is usually money. Hence, this song has a theme of appreciation. In thanking the king for making time to be with them and also giving them something to cool their throat, they perform this song for him in return. The nativized word mudaasi 'thank you' is borrowed from the Akan which is also used in this song to express the same meaning. Mbo 'well done' is also used in the song by the performer to put more emphasis on the level of excitement the performers are to the king for his kind gestures.In line 5, the performer used Gungəna zuи yee! 'The first

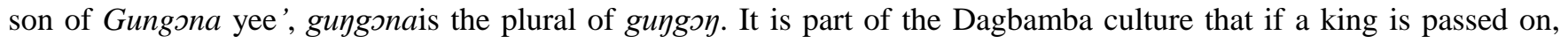
some chiefs (not all chiefs) when they arrived in the funeral, usually announce their presence through gun shots. The process of announcing ones presence in the funeral is termed among the Dagbamba as guygoykpebu. By extension, the king announces his presence in any gathering through gun shots. So because the king's father announced his presence in several gatherings, the performer praises the king that those who announce their presence in gatherings first son.Tibayba is a proverbial name to mean 'we have known them.' This was a name chosen by one of the wives of the grandfathers of the king. The Dagbamba can also call their grandfathers as shira apart from yaba.So in line 13, the performer is trying to establish the family tie the king has with Tibayba when the performer said Tibayba shira yee! 'Tibayba's love/grandchild/grandfather yee!' in the performance.Singers are termed as the wives of the king. But sometimes a lady gets exciting treatment from a man when the fellow is still a lover to the man. Because of this, for the singers expecting this kind of treatment from the king they prefer being termed as the lover to the king than the wife. So the performer in the performance said in line 18 that A mam puhiri a mudaasi yee! 'Your love says thank you yee! With this, the performer is the lover and thanks the king for coming out to be with them and also giving them something. 
In the same vein, the performer in trying to tell the king that she is a daughter to a tom-tom beater, she introduced in

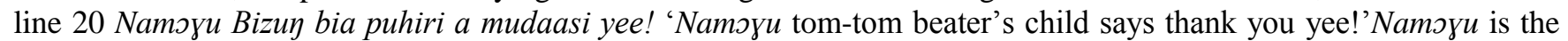
town where tom-tom beating started and the person who started beating tom-tom was calledBizuๆ. So when anybody mentions that she/he is Bizuy bia, it means that person is a tom-tom beater.

\section{Literary terms}

The most interesting and attractive aspect of most literary works and the identification and analysis of features of any art form is one of the important aspects of the study of literature. Literary devices are techniques employed by the performers to enable them produce special effect in therepertoire. This may be readily observed from the structure of the Dagbamba Damba repertoire particularly in the use of literary devices. This, they achieve through the use of sounds or words and logical meaning contained in these words as oral literature is that kind of literature delivered by word of mouth to the audience. Some of these literary terms employed in the repertoire include, repetition, assonance, alliteration, symbolism andimagery. These devices are discussed below.

\subsection{Repetition}

This is the most frequently employed literary term in a Dagbamba Damba repertoire performance. When employed by the performer, it makes the message of the song clearer or emphasize the significance of the recurrent words or phrase in the entire repertoire. The performer also employ repetition of some words several times in a repertoire so as to create melodic effect.In excerpt $1, t i$ 'our' is restated to put more emphasis on the performers being the subjects and ownership. Naa 'king' also repeatedly used in the song to emphasize on the significance of the word, and also link what the performers own and the receiver of the action or the idea of 'greeting' in the song.In excerpt 2, the performer repeats the word mali 'create/fix up' is ironically used repeatedly to lure the performers into a state of expectation. Again in the same excerpt, waa 'dance' is restated several times to put more emphasis on what is missing in the performance though waa 'dance' is been used ironically to mean concentration/sanity. The performer in the case of waa 'dance' employs 'epanalepsis' repetitive type as in some cases waa 'dance' appears at the end of a line and also at the beginning of the next line.In the same vein, for making the idea of the performers' message in the repertoire clearer, the performer restates the wordkani 'not there' and also to put more emphasis on the significance of the action 'create/fix up' or the idea of one creating/fixing up what is missing in the performance of the repertoire. That is, bringing back the concentration of all the performers into the performance. In excerpt 3 also, binsaa 'diarrhoea' is repeated so as to create a melodic and enhance rhythmic effects in the repertoire. It is also ironically used to lay more emphasis on the significance of the result of the action or the idea of what happens next when found guilty of low concentration.Miri'be careful' is restated to emphasize on the idea of taking precautions against certain actions. For an action that is about to be taken, the performer repeats the statement Wabigu yen no ma yee! 'Elephant is going to step on me yee!' to create the link of the action or the idea in the repertoire.To emphasize on the level of excitement of the performers by the present, the performer thus restate mudaasi 'thank you' and mbo 'well done' in the last excerpt. Therefore, the performer of the Dagbamba Damba repertoire employs a repetitive technique to either lay emphasis, create a melodic or rhythmic effect and or serve as a link of ideas in a repertoire.

\subsection{Assonance}

To reinforce the meaning of words or set the mood, the performer employs resembling sounds that are found within syllables of nearby words, arising particularly from the rhyming of two or more stressed vowels but with different consonant sounds.The performer in the performance of excerpt 2, employs repetition of the sound /a/ and sometimes in its long form in almost all the last syllables of both the lead vocalist's performance and the chorus. For instance, the performer repeated the sound /a/ in mali waa, ni a yina mali waa, waa kanialmost all the syllables. Also in excerpt 3 , the same sound is used in the last syllables of binsaa, biaand $m a$ in the chorus of this performance. With this, the performer creates rhyming which also serves as a building block within the song. Again, the performer in the performance of all, employs the literary repetition of the sound /e/ in its long form in all the last syllables of excerpt 4 and in some of the last syllables of the Dagbamba Damba repertoire for rhyming and also to be building blocks within the song.It is established therefore that, the Dagbamba Damba repertoire literary makes use of assonance to create a rhyme and also to serve as a building block within the repertoire.

\subsection{Alliteration}

Alliteration is a phenomenon of most of the Dagbamba Damba repertoire when a chain of words within a line or words closer to each other have the same first consonant sound. As one of the styles in performing,the performeremploys the use of the same first consonant sounds in the performance of the song. This enables the performer to place important ideas and messages in strategic places throughout the repertoire. 
The sound $/ \mathrm{m} /$ repeatedly appeared in the verse $\boldsymbol{M}$ puhiri $\boldsymbol{m}$ mam 'I greet my love' of line 16 of excerpt 1 , serves as a building block in the song just to enhance the sound effect. The repetition of the sounds $/ \mathrm{b} /, \mathrm{n} / \mathrm{and} / \mathrm{s} /$ at the beginning and middle of the word binsaa 'diarrhoea' respectively, is employed by the performer to place the important idea or message of the results of not concentrating throughout the performance of this song. This also creates a rhythmic sound pattern in the song performance.To place much premium on the words Mudaasi'Thank you'andMbo 'Well done' in excerpt 3 , the performer employs alliteration by repeating the consonant sounds $/ \mathrm{m} /, / \mathrm{d} /$ and $/ \mathrm{s} /$ in $\boldsymbol{m}$ udaas $i$ and $/ \mathrm{m} /, / \mathrm{b} /$ in mbo. This focuses the attention of the performers on the importance of appreciation in the song. All the repeated consonant sounds in the Dagbamba Damba repertoire are employed by the performer to serve as building blocks and also to enhance a rhythmic sound effect.

\subsection{Symbolism}

This is a literary term employed by the performer in most of the repertoire as the performer tries to convey certain important truth or lessons about the Dagbamba and existence problems employing less familiar objects or events within their environment to explain the abstract ideas.For instance, Gbuyim' baligu 'younger lions' are familiar animals the performer uses to explain the abstract ideas. The abstract ideas are the gatethe king is coming from and the symbol of chiefdom of the kingdom. One can only ascend to the throne to become the king of Bimbilla through the Gbuyima yili'Lion gate' or Baya yili'Ring gate'. So the performer is using also the lion to explain the kind of powers that has been handed to the king through the ancestors of the same gate and the powers the king possesses.Again, the performer used zuyukpuna 'clean-shaven heads' to explain the abstract idea of the state of the hairs of the king. The king is always in clean-shaven head but because he always wear either a hat or towel one cannot see it. Therefore, by the explanation the clean-shaven head is part of the dressings of the king.

\subsection{Imagery}

It is a literary term employed by the performer of the Damba repertoire to create mental pictures with words. The performer employs some words to create some pictures in the minds of the audience.It is also employed to create visual representations of actions, objects and ideas in our mind in such a way that they appeal to our physical senses.Excerpt1 in its performance, creates a picture of the posture a subject will be in greeting the master/king mentally in the audience. This will mean squatting and clapping alongside as responds because it is only the king who does the greetings. The Dagbamba believe it is the elder who greets and the younger only responds, so when a child meets the elder, he/she only squats and wait on the elder to greet for a responds. Excerpt 2 when performed creates bad impression in the minds of the audience about the performance. The audience when listened to this performance get pricked that all is not well with the performance and the king could come out of the chamber any time soon.In the performance of the third excerpt, the picture of an elephant about to step on something is mentally drawn in the minds of the audience. Everybody protecting him/herself from been stepped on and wondering what will happen to the person when the elephant steps on him.It is therefore the imaginations and visualization of the connections or relationships that are found in a performance that the performers use in performing. Thus the performer visualizes the image created in the performance and look around the environment to determine the image that is connected or has a relationship with the performance.

\section{Conclusion}

In conclusion, it could be said that the Dagbamba Damba repertoire goes beyond the purpose of practice and entertainment.Theyarenot haphazardly performed but have specific repertoire for specific purposes of which I have exemplified in the paper by showing the opening/introductory, the invitation, the welcoming and the goodbyingrepertoire. It is also worth noting that any song apart from the ones discussed in this papercould be performed to end the performance of the repertoire.

The repertoire has short verses as a form and the number of stanzas in a song cannot be easily determined since the performer is not conscious of the formal grouping that characterise a stanza.Though, the themes of reverenceand fidelity are the major themes that run across this entire repertoire,asong can also have a major theme such as caution, obedience and appreciation as pointed out in the paper.

The Dagbamba Damba repertoire session is an important activity in the celebration of the festival,since it is done to keep the emotional bond between the ancestors and the living and also to comfort the king in the night after a hard day's work. 


\section{References}

Ababio, K. E. (2005). The Nature and Dynamics of Culture and its Social, Moral and Religious Dimenssions . Journal of Science and Technology Vl 125.2, 91-102.

Abdulai, S. (2008). Names that prick: Royal praise names in Dagbon, Northern Ghana. PhD diss.,. Indiana University. Agyekum, K. (2007). Introduction To Literature 2nd Ed. Accra: MediaDESIGN.

Bodomo, A. (1996). On Language and Developmrnt in Africa: The Case of Ghana. Nordic Journal of African Studies, $5(2), 31-35$.

Edited by, V. S. (2013). Practical Criticism. India : Macmillan Publishers.

Finnegan, R. (2012). Oral Literature in Africa. Cambridge, Uk: Open Book Publishers.

House, H., \& Storey, G. (1959). The journals and Papers of Gerand Manley Hopkins. London: Oxford University Press.

Jakobson, R. (1966). Grammatical Parallelism and its Russian Facet. Language 42 (2), 399-429.

Kofi, R. L. (2006). Dagbani Proverbs. Tamale: Tamale Institute of Cross-Cultural Studies.

Mahama, I. (2004). History and Traditions of Dagbon. Tamale: GILLBT Printing Press.

MacGaffey, W. (2013). Chiefs, Priests and Praise-singers: History, Politics, and Land Ownership in Northern Ghana. USA: University of Virginia Press.

Okpewho, I. (1992). African Oral Literature. Bloomington adn Indianapolis: Indiana University Press.

Partnership, L. a. (2007). Dagbang Kaya ni Yelikura. Tamale: Ghana Institte of Linguistics Literacy and Bible Translation.

Pazzack, A. P. (2013). Dagbani An Introductory Course for Beginners. Koforidua: Pedaddo Ventures.

Roger, B. (2004). Dagbani-English Dictionary. Tamale: Tamale Institute of Cross-Cultural Studies.

Rashid, M. A. (2017). Linguistic Relativity among the Dagbamba. International Journal of Innovative Research and Advanced studies (IJIRAS), 4 (11) 200-205.

Ruth, M., \& Greenberg, R. A. (1992). Poetry: An Introduction. The Macmillan Press: China.

Saanchi, J. A. (1992). The Dagaaba Dirge: A Study of its Structure and Style. MPhil. Thesis. Legon: Department of Linguistics, University of Ghana.

Sanortey, T. D. (2012). The Aesthetics of Kontomboorl Songs Among the Birifor. MPhil Thesis. Winneba: University of Education.

Tia, S. (1969). Dagbang Kaya ni Wahi. Accra: Bureau of Ghana Languages.

Wyatt, M. (2013). Chiefs, Priests, and Praise-Singers: History, Politics, and Land Ownership in Northern Ghana. Charlottesville and London: University of Virginia Press. 